\title{
Prospects for Organization Theory in the Early Twenty-First Century: Institutional Fields and Mechanisms
}

\author{
Gerald F. Davis \\ Stephen M. Ross School of Business, University of Michigan, 701 Tappan Street, Ann Arbor, Michigan 48109-1234, \\ gfdavis@umich.edu \\ Christopher Marquis \\ Harvard Business School, Morgan Hall 312, Boston, Massachusetts 02163, cmarquis@hbs.edu
}

\begin{abstract}
$\mathrm{T}_{\mathrm{r}}^{\mathrm{h}}$ his paper argues that research in organization theory has seen a shift in orientation from paradigm-driven work to problem-driven work since the late 1980s. A number of paradigms for the study of organizations were elaborated during the mid-1970s, including transaction cost economics, resource dependence theory, organizational ecology, new institutional theory, and agency theory in financial economics. These approaches reflected the dominant trends of the large corporations of their time: increasing concentration, diversification, and bureaucratization. However, subsequent shifts in organizational boundaries, the increased use of alliances and network forms, and the expanding role of financial markets in shaping organizational decision making all make normal science driven by the internally derived questions from these paradigms less fruitful. Instead, we argue that problem-driven work that uses mechanism-based theorizing and research that takes the field rather than the organization as the unit of analysis are the most appropriate styles of organizational research under conditions of major economic change-such as our own era. This sort of work is best exemplified by various studies under the rubric of institutional theory in the past 15 years, which are reviewed here.
\end{abstract}

Key words: organization theory; social mechanisms; organizational fields; paradigms

Organization theory has found itself at an interesting crossroads at the turn of the century. On the one hand, we are constantly reminded that we live in a world in which large organizations have absorbed society and vacuumed up most of social reality (Perrow 1991). Multinational corporations (MNCs) have transcended political boundaries in their sales and their production processes, and dozens of them have annual revenues that surpass the GDP of all but a few nations. Their employees are like citizens with rights, benefits, and legalistic grievance procedures (Dobbin and Sutton 1998). Just as nation-states in centuries past came to be the dominant locus of power through their monopoly on the legitimate use of physical force, MNCs dominate the world economy (and thus society) through their concentrated control of capital. States are largely stuck with agreed-upon land borders, but MNCs and their mobile investments get to choose their jurisdictions in the marketplace of laws. It hardly seems a fair fight, as large organizations continue their drive to vacuum up whatever is left of social life. This situation locates organization theory as the queen of the social sciences, uniquely able to explain the dominant social structures of our times.

Yet close inspection by our theoretical confreres in law and economics reveals most organizations to be mere legal fictions with no "inside" or "outside" analogous to borders-they are simply dense spots in networks of contracts among sovereign individuals (who may themselves be mere fictions-Jensen and Meckling 1976). With corporations, there is no there there-they are simply legal devices with useful properties for raising finance. While counting new incorporations may give the impression that we are living in a Cambrian Explosion of organizations (Aldrich 1999), counting may not be that informative. It is trivially easy to incorporate in the United States, with or without a recognizable organization. Enron had upwards of 3,500 subsidiaries and affiliates, often organized as corporations or limited liability companies-entities that were often both legal and accounting fictions. Original equipment manufacturers (OEMs) routinely market products designed, manufactured, and distributed by other firms. Firms have no more long-term attachment to their employees than consumers do to their grocers (Alchian and Demsetz 1972). Coase (1937, p. 388, quoting Robertson) noted that in a market economy "we find 'islands of conscious power in this ocean of unconscious cooperation like lumps of butter coagulating in a pail of buttermilk," but it is becoming increasingly difficult to distinguish the lumps, much less count them. By some accounts, the imposing objects of organization theory have evaporated. No longer queen, organization theory may be more like the phrenology of the social sciences. 
This paper argues that an appropriate aspiration for organization theory in the early twenty-first century is providing a natural history of the changing institutions of contemporary capitalism. By natural history we mean explaining patterned variation over time: how do specific ecosystems of institutions change? Institutions are the sources of social and economic order-whether organizational or otherwise. Contemporary capitalism highlights the prominent economic trends of our times: globalization in finance and trade flows, postindustrialism and the declining importance of manufacturing relative to service in advanced economies, and a predominant place for financial markets in generating both order and disorder. North $(1990$, p. 6) argues that "the central puzzle of human history is to account for the widely divergent paths of historical change. How have societies diverged? What accounts for their widely disparate performance characteristics?" Organization theory has a distinctive toolkit for addressing this puzzle as it plays out today, including a well-elaborated set of theoretical mechanisms that can illuminate how macrolevel changes (e.g., governmental policies to eliminate discrimination, the growth of the environmental movement, a bursting asset price bubble) have their impact on the ground. This is a pivot point in the academic division of labor, a crossroads between sociology, economics, psychology, and political science. Put simply, organization theorists are best placed to address some of the critical questions of our time because organizational processes are often the drive train by which social and economic change are effected. As Lounsbury and Ventresca (2002, p. 6) point out, this would in effect be a return to the sociological approach to organizations of the 1950s, when "organizations were seen as sites for understanding the constitution and consequences of modern forms of power" rather than objects of theory in their own right. A review of recent work suggests that the field has largely moved in this direction without particular conscious guidance (see Davis 2005 for a full account). Moreover, we argue that new institutional theory has the best chance of accomplishing these understandings because it focuses on fields, mechanisms, and change, particularly market "incursions" into traditionally stable fields, of the sort most common today.

The paper is organized as follows. We first argue that empirical work in organization theory has shifted over the past two decades from paradigm-driven research, in which topics to be studied flow directly out of problems of theory, toward problem-driven work oriented toward events in the world. We argue that this shift follows from three factors: changes in the composition of organizational fields in recent times, changes in the empirical relations among core constructs in the theories, and a greater sensitization to cross-national differences and what they imply for general theories of organization. We describe social mechanisms and their place in theories about organizations. We argue that problem-driven work drawing on (organizational) mechanisms is particularly apt during a time of significant social and economic transitions, when the explanatory power of old theories has broken down. We then review studies in the tradition of new institutional theory that exemplify the kind of mechanism-based theorizing that we advocate. We conclude with some implications for what organization theory can and should look like going forward.

\section{Organization Theory: From Paradigm-Driven to Problem-Driven ${ }^{1}$}

For the first decade after the foundational statement of March and Simon (1958), organization theory had the prospect of following a single paradigm. As in the bureaucracies described by March and Simon, the field could decompose the problem of understanding organizations into subproblems amenable to discrete pieces of research that might aggregate back up into a grand theory of organizations. One might study the inducement/contribution theory, or problemistic search, or the operation of departmental information filters, with the expectation that the findings would add up to an understanding of organizations. Thompson's great 1967 synthesis Organizations in Action summarized the results of the intervening years of research and, along with Lawrence and Lorsch (1967), pointed the way to a more contingent model of organization. In subsequent years, the field brachiated into a set of partially overlapping, partially competing theories of organization. Transaction cost economics focused on where organizations placed their boundaries and how relations among separable parts were governed (Williamson 1975). Resource dependence argued against the efficiency orientation of economic approaches and posited that much of an organization's structure and action repertoire flowed from its position in networks of exchange and the power imbalances these created (Pfeffer and Salancik 1978). New institutional theorists focused on the symbolic nature of much organizational action and structure and their decoupling from internal operations, oriented as they were toward the requirements of external evaluators (Meyer and Rowan 1977). And organizational ecologists argued that bureaucracies were prone to such rigidities that the most sensible research approach was not to study internal dynamics and adaptation, but the births and deaths over extended periods of different forms that were more or less fit for their selection environment (Hannan and Freeman 1977).

Theoretical debates among divergent paradigms can be a positive sign of health for a discipline, and the waning hegemony of a single approach may signal maturation. Baum and Rowley argue that "a diversity of perspectives need not lead to fragmentation and a lack of consensus.... Indeed, multiple views are vital to 
scientific advancement" (2002, p. 23). The elaboration of divergent perspectives allows for critical tests that advance scientific understanding - and may the best theory win (Stinchcombe 1968). Indeed, the burst of foundings of new theories in the mid-1970s is something that students of organizations might have expected from Stinchcombe's (1965) discussion of social structure and organizations. Presumably, a winnowing process would follow to select out the weak theories and allow the strong to survive. Research following the theory proliferation tested core ideas in each of these divergent approaches, and scholars occasionally found contexts to conduct critical tests (e.g., Singh et al. 1986). One might have hoped to see another grand synthesis at the end of the 1980s that selected judiciously from the competing paradigms, drawing on meta-analyses of the cumulative bodies of findings in each approach (Aldrich 1999). Based on this synthesis, new work could proceed to cumulate knowledge in ever-greater territories of organizational life.

Yet nothing of the sort has happened. Instead, with the notable exception of population ecologists, macro-organizational scholars since 1990 have largely abandoned the idea of cumulative work within a particular paradigm in favor of problem-driven work that is theoretically agnostic. To document this, we classified 89 articles published in Administrative Science Quarterly from 1991 through 2001 that could be categorized as contributions to organization theory. We found that 10 articles $(11 \%)$ followed a theory-testing model in which the research question flowed directly from the logic of a particular theory. In each case the ultimate dependent variables were organizational birth and/or death rates, while the independent variables included organizational density and competition, change, and governmental regulation. Outside of ecology, however, the problems that occupied researchers' attention were, in general, broadly topical, and the approaches theoretically eclectic. With a few exceptions, empirical studies examined events from the past few decades: corporate acquisitions (who did them, what advisors they used, how much they paid, where the targets were located), takeovers (who was threatened, how they responded), boardroom dynamics, alliances, diversification and strategic change, and so on. Moreover, the broader questions were often core sociological problems for which organizations mediate between economic and social forces and individual or collective outcomes. How have Japanese firms' labor practices changed in response to the extended economic downturn? What is the organizational texture of China's transition to capitalism? How do market pressures change the way health care is delivered? How do corporate elites maintain their power in the face of challenges arising out of "shareholder capitalism?" The most engaging recent work has sought to make sense of the intersection of biography and history in social structures, as Mills (1959) urged long ago. It happens that the social structures that matter are often organizational structures (Lounsbury and Ventresca 2002).

We want to be clear that by "problem-driven work" we do not imply that the research was intended to provide solutions to the problems faced by business managers (although it may have been). Rather, problem-driven work is distinguished by its orientation toward explaining events in the world-starting with the question "why is it that...?" Paradigm-driven work, in contrast, begins with hypotheses deduced from theory intended to be general. Events in the world are primarily contexts for testing those hypotheses in paradigm-driven work. Stokes (1997) argues in the case of the natural sciences that the distinction between "basic" and "applied" is a false dichotomy: Research can be driven by a quest for fundamental understanding with no prospect for use (Bohr's quadrant), for individual, group, or societal use without regard for fundamental knowledge (Edison's quadrant), or fundamental knowledge inspired by use (Pasteur's quadrant). (Research may also be done with neither use nor fundamental knowledge in mind, e.g., lab training.) In the post-war era, he argues, Pasteur's quadrant-knowledge for use-has been the source of the most significant scientific advances. By the same token, some of the great advances in social scientific thinking have taken the form of problem-driven work. Arguably, both the 18th Brumaire of Louis Bonaparte (written during the time that Napoleon's nephew and his followers were dissolving the assembly and establishing a dictatorship) and The Protestant Ethic and the Spirit of Capitalism are problem-driven works in the sense we have described.

Why the shift from paradigm-driven to problemdriven work in organization theory? There are several likely causes. First, the product of the Cambrian Explosion of organization theories in the mid-1970s appears in retrospect to be a set of divergent perspectives on American organizations, especially large firms, from that peculiar era. American firms might have vertically integrated their suppliers with high asset specificity, diversified out of industries that were overly constraining, adopted a set of decoupled structures to ward off outside evaluators, and become structurally inert in the process. However, like Nixon, disco, and polyester clothing, these were not necessarily permanent features of the social landscape. Manufacturing conglomerates largely disappeared in the United States during the 1980s, alliances and other networks displaced vertical integration, the financial revolution drastically changed the character of outside evaluators for public corporations and other traded entities, and constant change became the cliché ordering business. Statistical relationships among variables turned out to be highly unstable over time; for instance, patterns of merger, acquisition, and executive 
succession looked wildly different in the 1960s and the 1980s. In the earlier decade, conglomerates run by social "outsiders" did the acquiring and single-industry firms were the targets, while in the 1980s it was conglomerates (now run by insiders) that were taken over and busted up while focused firms were largely safe. (One possibility, of course, is that such instability is a sign of low internal validity-see Cook et al. 1990, p. 497.)

In hindsight, it seems naïve to have imagined that things could have been otherwise. Harvey (1990, p. 343) notes that producing novelty, in products and organizations, is one of the essential features of capitalism: “... capitalism creates its own distinctive historical geography. Its developmental trajectory is not in any ordinary sense predictable, precisely because it has always been based on speculation-on new products, new technologies, new spaces and locations, new labor processes... and the like... . There are laws of process at work under capitalism capable of generating a seemingly infinite range of outcomes out of the slightest variation in initial conditions or of human activity and imagination." By the 1990s we saw a flowering of organizational forms, from a revival of preindustrial putting-out systems (Lazerson 1995) to forms that would have been unimaginable a few years prior. "Web-based retailer" would not be a comprehensible phrase in 1993; in 1999 there were hundreds of them; and in late 2003 one of them (Amazon.com) had a market capitalization that approximated that of General Motors, the world's largest manufacturer. As Sabel and Zeitlin (1996) put it, "It is as though the prehistoric and imaginary creatures in the industrial bestiary had suddenly come to life."

Cross-national research highlighted the idiosyncrasy of the United States and its large organizations. For example, while industrial districts were regarded as an extinct form in the United States (when they were considered at all), they provided longstanding and robust alternatives to vertical integration elsewhere in the world (Piore and Sabel 1984) and evidently a good model for organizing high technology industries (Saxenian 1994). American managers were protected from their shareholders by the dispersed ownership that accompanied large corporate size-the famous separation of ownership and control. However, outside the United States and the United Kingdom, the vast majority of large corporations had dominant shareholders, either founding families or governments, who were not removed from active management (Davis and Useem 2002). Business groups, relatively rare in the United States, turned out to be pervasive in other economies, making the separable, countable, autonomous organization of American organization theory the rare exception rather than the rule (Granovetter 1994). Some even argued that Western theoretical views of atomistic firms reflected a general ethnocentrism that revealed itself in pervasive misunderstandings of East Asian enterprise (Biggart and
Hamilton 1992). Indeed, legal scholars find that the question "How do we know when an enterprise exists?" is often in principle unanswerable in China, given inconsistent approaches to recognizing firms among diverse governmental agencies (Clarke 2003).

Finally, there is an increased sophistication about what social science can achieve with respect to organizations. The notion of a "theory of organizations" now seems like naïve scientism, like a theory of diesel trucks, or a theory of hitchhiking. Organizations simply are not the kind of thing amenable to general theory. Applying a template to organizational phenomena (such as an open systems schema of inputs, transformation processes, and outputs) often obscures more than it illuminates in the case of the postindustrial organizations that surround us today. A brief case example follows. At the start of the 1990s Westinghouse was a 100-year old industrial conglomerate employing upwards of 100,000 people. During the next decade, it sold off a number of industrial businesses, acquired broadcaster CBS, liquidated its remaining industrial operations (shedding half its employees), changed its name to CBS, moved its headquarters from Pittsburgh to New York, and was acquired by Viacom, where it is now part of a stable of media properties. This shift—in product, industry, employees, identity, and geography-does not accord well with any of the theories we have mentioned, and while extreme in degree, it is far from unique. If not predictable, we can at least hope to make such changes explicable, and a single general contingency theory of organizations will not be up for the task.

There are dangers to a discipline that lacks a dominant paradigm to guide the accumulation of knowledge (Pfeffer 1993). Lab psychologists can do meta-analyses and come to some conclusions that might generalize (Aldrich 1999), but problem-driven work risks being simply business journalism with regressions. The value of cataloguing novelty may not be self-evident. And theoretical eclecticism can easily degenerate into laundry lists of variables to include in statistical analyses. Sørensen (1998, pp. 238-239) laments the "fascination, if not an obsession, with statistical models and concerns, and a neglect of the need to develop sociological models mirroring conceptions of mechanisms of social processes" leading to statistical models with "a conceptually meaningless list of variables preventing any kind of substantive conclusion" (p. 243). Our assessment is that the next step for organization theory is not to find and enforce the singular overarching paradigm (as some read Pfeffer 1993 to say), but to move toward mechanismbased theorizing about change in the world of the sort that recent work in new institutional theory exemplifies.

\section{Mechanism-Based Theorizing}

How are we to proceed without Theory? What System of Thought have these Reformers to present to this 
mad swirling planetary disorganization, to the Inevident Welter of fact, event, phenomenon, calamity?... Show me the words that will reorder the world, or else keep silent. If the snake sheds his skin before a new skin is ready, naked he will be in the world, prey to the forces of chaos. Without his skin he will be dismantled, lose coherence, and die... (speech by Aleksii Antedilluvianovich Prelapsarianov, world's oldest living Bolshevik, in the Kremlin's Hall of Deputies, from Angels in America, Part 2: Perestroika; Kushner 1994, pp. 13-14).

What do we mean by mechanism-based theorizing? Social mechanisms are "sometimes-true theories" (Coleman 1964, p. 516) that provide "an intermediary level of analysis in-between pure description and storytelling, on the one hand, and universal social laws, on the other" (Hedstrom and Swedberg 1998). If a regression tells us about a relation between two variables-for instance, if you wind a watch it will keep runningmechanisms pry the back off the watch and show how. Mechanisms describe "a set of interacting parts-an assembly of elements producing an effect not inherent in any one of them. A mechanism is not so much about 'nuts and bolts' as about 'cogs and wheels'... - the wheelwork or agency by which an effect is produced" (Hernes 1998, p. 74). Hedstrom and Swedberg (1998) collect several examples of mechanism-based theories in sociology: the self-fulfilling prophecy in which an initially false definition of a situation evokes behavior that makes it become true (e.g., a run on a bank), diffusion through networks in which actors adopt an innovation because their network contacts have previously adopted, and threshold-based behavior in which an actor's propensity to join in a collective action depends on his or her observation of a number of others who have already joined in. In each case, collective outcomes (bank runs, widespread adoption of an innovation, collective action) result from individual actors observing what others have done, which shapes their own propensity to take that action, which in turn makes them evidence for the next actor.

A general typology of micro/macro linkages includes situational mechanisms (from macro to micro), actionformation mechanisms (from micro to micro), and transformational mechanisms (from micro to macro) (Hedstrom and Swedberg 1998, pp. 22-23). McAdam et al. (2001, pp. 25-26) provide an alternative typology oriented toward political outcomes, such as in social movements: environmental mechanisms ("externally generated influences on conditions affecting social life"), cognitive mechanisms ("operate through alterations of individual and collective perception"), and relational mechanisms ("alter connections among people, groups, and interpersonal networks"). These mechanisms are especially apt for making sense of social change processes and are broadly applicable to organizational phenomena in times of economic transition.
Campbell (2005) further catalogs a number of mechanisms that have been used in the study of organizations and social movements: framing (the use of metaphors and symbols that organize perceptions of issues and cue courses of action by linking problems and actions to prevailing cultural conceptions), diffusion (the spread of ideas, structures, and practices, often via networks), translation (how ideas that diffuse are modified and implemented to work in specific local contexts), bricolage (recombining elements, often borrowed from other contexts, to create a new configuration of social activity), network cultivation and strategic leadership (or institutional entrepreneurship). Stinchcombe (2002) adds three more: commensuration (the institutional process by which entities become comparable and thus competitors, as firms in an industry), evangelism (the reverse of diffusion, where adopters or their agents eagerly spread organizational practices), and the bases of truth telling. Of course there are many more mechanisms than those in this brief set, but this gives a sense of the shape of the domain.

Importantly, mechanism-based theorizing can aspire to explain but not predict. Elster quotes George Vaillant: " "Perhaps for every child who becomes alcoholic in response to an alcoholic environment, another eschews alcohol in response to the same environment' ... Both reactions embody mechanisms: doing what your parents do and doing the opposite of what they do. We cannot tell ahead of time what will become of the child of an alcoholic, but if he or she either turns out to be either a teetotaler or an alcoholic, we may suspect we know why" (Elster 1998, p. 45). The quest for novelty in capitalist economies suggests that we will often be in this situation: confident that actors will respond to particular pressures, but uncertain in what direction. Thus, we may be able to explain afterward but not predict prospectively.

In some sense, mechanism-based work is a return to organization theory's roots. March and Simon's explanation of hierarchy in terms of bounded rationality is a superb example. How are cognitively simple individuals able to accomplish ends far greater than themselves? They may accomplish this through the differentiation of subunits into mental bite-sized chunks and the artful reaggregation of those chunks via a hierarchy. Their 1958 book is a masterpiece of mechanism-based theorizing about what organizations do. Subsequent work added new mechanisms to our portfolio. We have many instances of selection processes (through differential births and deaths, through takeovers, through legal changes). We have countless studies of diffusion, through networks and otherwise (see Strang and Soule 1998 for a review). We know how industry concentration can prompt the births of specialists through resource partitioning (Carroll 1985). Network structures and their consequences are now reasonably well 
documented (Burt 1992). The formats of transaction cost-minimizing contracts are diffused through the literature. The legacy of several decades' research is, in short, a virtual compendium or toolkit of organizational mechanisms, albeit one that has not been well catalogued as such.

Importantly, in contemporary work organizations are often not the object of explanation but its subject. That is, researchers are prone not to ask why are there so many kinds of organizations but how do organizations act as the wheelwork producing a social outcome? (such as stratification, or state policy, or labor mobility). "Doing organization theory" does not signal that one is seeking to explain, say, why is there hierarchy? (pace March and Simon 1958). Rather, organization theory is best seen as a commitment to a level of analysis, an organizational mode of explanation. The point is not to accumulate findings about what is generally true about organizations - this proves to be a fruitless endeavorbut to use organizational mechanisms to explain social phenomena, to locate the "intersection" Mills (1959) wrote about.

\section{Examples from New Institutional Theory}

Institutional theory, broadly construed, has the best chance of accomplishing the aspiration for organization theory that we have described. Most obviously, institutions are the core construct of the approach. Scott (1995, p. 33) defines them as follows: "Institutions consist of cognitive, normative, and regulative structures and activities that provide stability and meaning to social behavior. Institutions are transported by various carriers - culture, structures, and routines-and they operate at multiple levels of jurisdiction." Second, this approach is distinguished by taking the field as the relevant unit of analysis and remaining agnostic about whether it is composed of organizations, individuals, or other combinations of actors: "The concept of field identifies an arena-a system of actors, actions, and relations-whose participants take one another into account as they carry out interrelated activities. Rather than focusing on a single organization or movement, or even a single type of organization or movement (population), it allows us to view these actors in context" (McAdam and Scott 2005, p. 10). By "field" we do not mean to invoke field theory as Martin (2003) defines it. Although he includes DiMaggio and Powell's (1983) version of new institutional theory under this rubric, we see their proposal to take the field as the unit of analysis as compatible with mechanisms, "an explicable chain of elements banging into one another" (Martin 2003, p. 16).

The players that populate fields and the nature of their play can change over time. For instance, medical care in the United States traditionally had a relatively simple organization. In 1950, physicians that were certified, and were dues-paying members of the American Medical Association saw patients and when appropriate referred them to local nonprofit community hospitals. Physicians, hospitals, and the AMA were the most important actors defining health care, and the AMA acted as a central gatekeeper preventing chiropractors, psychologists, faith healers, and cosmetologists from joining their "field." By 1990, health care included free-standing clinics for dialysis, plastic surgery, and drug abuse treatment, for-profit HMOs, and dozens of new medical specialties organized into a range of new forms and represented by a wildly brachiating set of professional organizations beyond the AMA, which no longer exercised the same exclusive control on entry into the field (Scott et al. 2000). Counting organizations within a particular industry would not in itself be an especially informative way to make sense of health care in the second half of the twentieth century; one must take a field-level approach, as indicated by institutional theorists (DiMaggio and Powell 1983).

A field-level approach is especially appropriate during unsettled times such as today, when new industry segments proliferate and when the boundaries around existing industries can shift from permeable to nonexistent. For example, in the United States the sharp legal divisions among commercial banking, investment banking, and insurance, and the geographical restrictions on the operations of financial institutions, were largely eliminated. This enabled the assembly of conglomerates providing every conceivable business and consumer financial service under one roof. Media and communications companies have similarly effaced the distinctions among "channels" (providing broadcasts, telephone service, cable television, broadband, and Internet access) and "content" (the stuff distributed over the channels). The inevitable term "media conglomerate" ends up providing very little information about what a company actually does. In such contexts, a field-level approach provides a useful framework for characterizing how settlements come about.

Consider Silicon Alley, the Web industrial district in the approximate vicinity of the Flatiron Building in New York that flourished during the late 1990s. At its formative stage, it was highly uncertain what Web businesses would actually do. Possibilities included retailing, auctions, data provision, media content, advertising, community services, and many others, as well as designing the websites for people and businesses. The "industry" included individual freelancers, small start-ups, and units of established companies in other industries. New entrants drew founders, employees, and business models from constituent industries that included software, journalism, advertising, retail, publishing, and broadcast media, prompting rampant institutional bricolage. Robbins (2002) studied the evolution of job titles in Silicon Alley, a fascinating cut on the problem of new industry formation. There was little agreement among 
Web practitioners about what tasks should be grouped together as a job, how jobs should be labeled, or how they should be filled (a failure of Stinchcombe's 2002 commensuration mechanism). What should firms claim to be looking for when recruiting employees- - content designers," "Web artists," or what? And what should potential employees or contractors claim to be? Clearly the nomenclature of employment is important for matching talent to tasks, yet Robbins (2002) found persistent idiosyncrasy in the titling of positions that had not reached a settlement by the time the financial bubble that held Silicon Alley aloft popped. Moreover, this case exemplifies a problem common across instances of industry convergence-whose language and assumptions about organizing wins when there is no hegemon to enforce the rules? The answer is not obvious in advance, but mechanisms can help provide an explanation for the process of settlement.

While industries typically morph out of prior industries, drawing on elements such as what to call jobs and how to organize work, the recycling industry could effectively date its founding to Earth Day 1970, when pressures from the environmental movement spontaneously created demand for a solution to the solid waste problem. Lounsbury (2001) examined how colleges and universities responded: Some simply added new responsibilities for recycling to their existing waste management departments, while others created new recycling departments, often managed by young activists. The latter schools were frequently distinguished by the fact that their students were connected to a national activist organization that disseminated tactics for activism and recycling implementation. Once in place, the activist-recyclers evolved into a self-organized profession, creating a national professional organization that helped members deal with the various pressures they faced. Moreover, once they were defined as a profession, they could generate best practices, spread standardized tools and techniques, and advocate for new "solutions" within their respective organizations-thus creating another overlay connecting members of the field of higher education.

Even in instances where an industry would seem to be reasonably well defined, a field-level approach proves essential for a full understanding of institutional change. Hoffman $(1999,2001 \mathrm{a})$ analyzes how the U.S. chemical industry responded to the advent of environmentalism from the early 1960s (when the publication of Rachel Carson's Silent Spring focused public attention on the environmental consequences of DDT) to the mid-1990s (by which point the Chemical Manufacturers Association had implemented a "responsible care program" of environmental principles binding on their members). Environmentalism had gone from heresy (perceived by industry members as the unscientific opinion of antiprogress fringe elements) to dogma, subscribed to by all responsible manufacturers (Hoffman 2001a). Hoffman defined the field not based on a common product or technology, but according to interest in and impact on a central issue: for chemical industry environmentalism, "Field membership was defined by who participated in the legal process and therefore had a voice in determining institutional norms regarding environmentalism" (Hoffman 1999, p. 364). One way to understand this issue is to examine lawsuits among organizations as a way to trace changes in field membership. Thus, over time members expanded from chemical manufacturers and their trade associations to governmental organizations (particularly following the creation of the Environmental Protection Agency in 1970) and nongovernmental organizations (such as environmental groups that filed lawsuits against alleged polluters), ultimately including insurance companies who were potentially liable for waste cleanup for their clients. These aggregate-level processes in turn shaped the activities of discrete firms within the industry by offering a delimited menu of feasible responses to pressures around environmental practice (Hoffman 2001b). Hoffman's work highlights processes of framing, diffusion, translation, and bricolage-all mechanisms identified by Campbell (2005).

While work on fields occasionally documents how actors outside the market, such as social movements, influence organizational fields, a recurring theme in much institutional research is how fields respond to market encroachment. That is, how do traditional practices change due to increases in market pressures (broadly defined)? Ahmadjian and Robinson (2001) examined the changing nature of the employment relation in Japanese firms during the 1990s. During the extended period of economic growth that Japan experienced from the 1950s to the late 1980 s, core firms were able to make (and keep) promises of long-term employment for their workers, recruiting college graduates who intended to stay with the organization for their entire careers. The sustainability of this practice was of course contingent on continuous growth. After the economic bubble burst around the turn of the decade, Japanese firms faced strong pressures to downsize their workforces, a practice quite common in the United States, yet an anathema in Japan. Firms that tried to shrink their labor forces, particularly large and visible firms that were not able to point to dramatic losses, found themselves subject to television exposés and protest demonstrations. Eventually downsizing occurred on a large scale, as firms found that if they shrunk their employment roles as part of a "herd," they were less likely to be singled out for opprobrium. Again, this represents a field-level approach that explains large-scale historical events by linking the actions of individuals (corporate managers) to collectives ("herds" of companies) through social mechanisms.

Field-level change in college publishing firms is demonstrated by the change in executive succession 
practices as publishers moved from an "editorial logic" (grounded in family ownership and strong ties between editors and authors) to a "market logic" (where publishing firms were often units of conglomerates evaluated by bottom-line profitability). Thornton and Ocasio (1999) document a shift in the allocation of power at the top of the publishing hierarchy as the field moved from the editorial to the market model, but more tellingly they argue that the rules of the game had changed: Why executives would leave depended on whether the industry was seen as a gentleman's game or just another commodity business. Such changes have implications for what kinds of "content" make it into print and thereby into the hands of college students. The field-level conception indicates that what counts as "good performance" for a publisher, and thus which executives are regarded as successes and failures, changes over time as new rules replace old.

Another exemplary study examined how rural hospitals responded to competitive changes in their environments. The changes in the composition of the field of health care described by Scott et al. (2000) generated a fair amount of competitive pressure for hospitals. While one might imagine that these organizations were stuck between a rock and a hard place, their administrators were often quite resourceful in constructing solutions to their problems. Hospitals transformed into diverse organizations within the broad field of "health care," including nursing homes, drug treatment facilities, and outpatient clinics (D'Aunno et al. 2000). This study shows the micro-structure of field-level change by demonstrating how actors of one type (hospitals) can transform into new types, changing the aggregate structure of the field (and moreover the availability of certain types of services for patients).

In the United States, the question of how human resource practices have responded to legal changes has received a fair amount of attention from Frank Dobbin, John Sutton, Lauren Edelman, and their collaborators, and they have generated a model to account for this process. While one might perceive governmental regulation to require firms to do certain well-specified things and to avoid others, law is often much more ambiguous particularly when it comes to corporate structures. (American corporate law is described as being generally enabling rather than mandatory.) The various Civil Rights acts of the mid-1960s are a case in point: Legal mandates to avoid discrimination do not exactly provide a roadmap to compliance. Firms experimented with various forms aimed at demonstrating compliance-equal employment policies, affirmative action offices, and others-until court testing showed one to be sufficient, after which the sanctioned approach diffused widely among firms (Edelman 1992). Moreover, whether the creation of new human resource offices was intended as a cynical façade detached from actual operations or a sincere effort to rectify past discrimination, the outcome was the creation of a constituency within firms for innovations in personnel policies and a professional network linking companies into a field with respect to their "human resources" (Sutton and Dobbin 1996). Human Resource professionals end up portraying their profession not as the hapless implementer of unwanted and ambiguous state policies, but as the originator of modern and progressive employment practices (Dobbin and Sutton 1998). Once again, field-level organizational mechanisms are the devices standing between governmental policy on discrimination and practices on the ground such as maternity leave and affirmative action that shape individual life chances.

Even in the core domain of shareholder capitalism, a field-level, mechanism-oriented approach provides distinctive insights into the large American corporation. The structures, practices, power relations, and general orientation of U.S. firms changed dramatically during the 1980s and 1990s as the ideology of shareholder capitalism (and its quasi-theoretical underpinning in agency theory) came to dominate the corporate economy. Hostile takeovers aimed at "unlocking shareholder value" were the most visible device for changing corporate practice, but (as with legislation against discrimination) corporate managers and boards were resourceful in how they responded. It is a truism of social psychology that, in the face of ambiguity, decision makers often take their cue from what other actors have done. For managers and boards, this often takes the form of following the lead of the firms with which they share directors or which are located in the same city. A comparison of the spread of poison pills (which make hostile takeovers much more difficult) and golden parachutes (which richly compensate those who lose their jobs after a hostile takeover) shows how mechanisms at the field level shaped aggregate corporate responses to takeovers (Davis and Greve 1997). Whereas pills spread rapidly through a board-to-board contagion process in which directors of firms that adopted them encouraged the other boards on which they served to adopt, parachutes spread slowly through geographic proximity-that is, firms adopted parachutes to the extent that others headquartered in the same city had done so. The divergent spreads of these devices reflects their legitimacy in the eyes of the relevant constituencies-corporate managers and directors. In contrast to their evaluations by shareholders, corporate directors typically considered poison pills to be unobjectionable but golden parachutes to be highly questionable. Given this background condition, the two innovations had rather different diffusion processes, with pills diffusing rapidly across the country and parachutes gaining prevalence much more slowly. Norms also varied by region. For example, most firms in Dallas had parachutes early, most in northern California never did.

Other studies that examine the geography of legitimacy include the analysis by Marquis (2003) of how 
traditions in corporate governance practice vary across local U.S. business communities. Communities that were established before the advent of air travel (i.e., that "grew up" prior to the 1920s) such as St. Louis maintained more densely connected corporate networks into the twenty-first century than younger communities of comparable size such as Phoenix. This network imprinting effect reflects local norms passed on by prominent local companies to newcomers. Thus, a new company in an established business community is more likely to appoint directors to its board from among local corporate peers than is a comparable new firm in a younger business community, which in turn socializes the newcomer into local practice.

As these studies show, a good working knowledge of organization theory provides a large toolkit of mechanisms-sometimes-true theories-for explaining the evolution of economic institutions, and there is sense in remaining agnostic ex ante rather than being wedded to, say, birth and death, or diffusion, or adaptation, as the true-or-false explanation. For instance, one of the central problems in the world economy today is convergence in corporate governance practices. There are many equally plausible explanations for whether and when firms or national systems of governance would move toward a common type. In a recent paper (Davis and Marquis 2005) we studied the most likely case for convergence: foreign firms listed on the New York Stock Exchange and Nasdaq. Prior arguments suggested that listing in the United States was a short path toward convergence on the American model. We contrasted several accounts that might have turned out to be true: Foreign firms might list in the United States only when they have already "turned American." Firms might turn American over time after listing in the United States. Firms might turn American to the extent that they are tied to American firms (e.g., through shared directors). Or old firms might remain inert, while new firms are "born American." Our results were consistent with the last explanation: While French firms privatized by the state are listed on the New York Stock Exchange and recruit American directors, they retain their distinctive practices over time. In contrast, Israeli biotech and startup software firms are in many respects indistinguishable from their Silicon Valley counterparts. One process of interest in the contemporary economy (convergence in corporate governance) was susceptible to four organizational explanations, but during the time we studied (the late 1990s) one turned out to be the most applicable sometimes-true theory, while we could tentatively rule out the others.

These examples do not describe the basis of a general theory of organizations. They are part of a natural history of a particular set of economically consequential institutions. Most of the findings we describe are highly context specific, describing how American firms in a federalized legal system responded to the Civil Rights Acts of the 1960s, or how Japanese corporations changed their employment practices in response to the end of the 1980s bubble economy. Thus, it makes sense for these accounts to be assembled from "bits of sometimes-true theories"- that is, from mechanismsrather than seeking the observed results as deductions from general covering laws. Note that these studies were problem driven not in the sense that they yield useful insights for managers, but because they are oriented toward explaining events in the world rather than chosen purely as contexts for testing hypotheses derived from theory.

\section{Implications}

We have argued that an appropriate goal for organization theory in the early twenty-first century is a better explanation of the economic institutions of our time. The studies we reviewed in the previous section provide guidance for how to do this: They exemplify problemdriven research drawing on organizational mechanisms to make sense of more or less singular historical occurrences in institutional fields. The aim of this work is not to generate a general theory of what organizations are or do, but to create an understanding of how historical shifts in economy and society have their impact on the ground (cf. Lounsbury and Ventresca 2002).

We close with what we hope will be useful thoughts for the future. First, how can we evaluate scientific progress in a discipline that is theoretically eclectic, rooted in mechanisms rather than paradigms? One sign of progress is that weak theories are selected out, as researchers favor progressive theories capable of accounting for observed regularities while making novel predictions (e.g., Baum and Rowley 2002). We are willing to assert that organization theory as a discipline has no history of such selection and little prospect for it in the future: The theories of the 1970s, for instance, continue to hang on independent of empirical confirmation, and efforts at disconfirmation are both rare and relatively ineffective. To our knowledge, no organizational theory has ever been "rejected" (as opposed to "falsified"). However this should not be surprising: Organizations are simply not the kinds of things susceptible to $a$ theory, and researchers in practice have largely abandoned the notion of a theory of organizations. An alternative form of progress is in the discovery (or creation) and refinement of mechanisms. The most productive theoretical work going forward will be in cataloging and developing organizational mechanisms. Mechanisms, unlike theories, are not falsified; rather, they are employed as tools for explanations (which can themselves be rejected, of course).

One might hold out hope that a general "theory of fields" will eventually fill the space held by organization theory. That is, rather than abandoning the idea of 
a unifying approach for the discipline, we might adopt an alternative that avoids the difficulties of taking organizations as units of analysis. Some have already declared victory in this regard (see Martin 2003 on new institutionalism). However this is premature: An appropriate lesson from the analysis of Stokes's (1997) "Pasteur's quadrant" is that problem-driven work is far more likely to produce basic understandings than armchair theorizing. This will remain the case at least until a stock of field-level studies with close attention to mechanisms has accumulated.

Three areas of research deserve the greatest attention in light of our argument for problem-driven work on contemporary economic institutions. First, relatively few studies (other than those we reviewed above) have taken seriously the injunction to study fields as units of analysis. As a result, our understanding of the empirical properties of fields is somewhat limited. The birth of new industries (e.g., the Internet industry) and blending of old industries (e.g., information and communication technologies, financial services, media) provide particularly rich contexts for studying fields and their genesis, as these are situations where the admissions standards and rules of play are revealed and contested. Second, market incursions into previously protected fields are an ongoing feature of contemporary life, as professional discretion gives way to financial rationalization in publishing, higher education, health care, the press, and elsewhere. Understanding the organizational impact of "marketization" as it occurs in new contexts is a pressing need for future research. Finally, while market incursions into sacred domains is a venerable part of modernization (see, for instance, the Communist Manifesto), the incursion of financial markets and their peculiar ontology is distinctly postmodern. One of the evident pressures is for corporations and those that run them to prove their merit relative to other financial assets (such as mortgagebacked securities or credit card debt bonds). The mechanisms of commensuration (Stinchcombe 2002) among financial assets, including corporations, are particularly apt subjects for future research.

We note in conclusion that our argument does not require a substantial change in current research practice. Indeed, a survey of the past decade and a half of research in the macro end of organization science shows that the field has already swung in the direction we describe, toward problem-driven rather than theory-driven work (Davis 2005). Beyond simple ratification of a change that has already occurred, however, we encourage a focus on fields and mechanisms: fields because substantial economic change does not stay contained within organizational or industry boundaries, and mechanisms because the quality of explanation is enhanced by an explicit focus on the cogs and wheels behind the regression coefficients. Such a turn would greatly enhance the prospects for organization theory in the early twenty-first century to provide useful understandings of the contemporary era.

\section{Acknowledgments}

The authors thank Ron Burt, Kim Elsbach, Scott Sonenshein, Kathie Sutcliffe, Marc Ventresca, Jim Walsh, participants in the Frontiers of Organization Science Conference, and two anonymous reviewers for helpful comments on an earlier draft.

\section{Endnote}

${ }^{1}$ The argument in this section draws on Davis (2005).

\section{References}

Ahmadjian, C. L., P. Robinson. 2001. Safety in numbers: Downsizing and the deinstitutionalization of permanent employment in Japan. Admin. Sci. Quart. 46 622-654.

Alchian, A., H. Demsetz. 1972. Production, information costs, and economic organization. Amer. Econom. Rev. 62 777-795.

Aldrich, H. E. 1999. Organizations Evolving. Sage, Thousand Oaks, CA.

Baum, J. A. C., T. J. Rowley. 2002. Introduction. J. A. C. Baum, ed. Companion to Organizations. Sage, London, UK, 1-34.

Biggart, N. W., G. C. Hamilton. 1992. On the limits of a firm-based theory to explain business networks: The Western bias of neoclassical economics. N. Nohria, R. G. Eccles, eds. Networks and Organizations: Structure, Form, and Action. Harvard Business School Press, Boston, MA, 471-490.

Burt, R. S. 1992. Structural Holes. Harvard University Press, Cambridge, MA.

Campbell, J. L. 2005. Where do we stand? Common mechanisms in organizations and social movements research. G. F. Davis, D. McAdam, W. R. Scott, M. N. Zald, eds. Social Movements and Organization Theory. Cambridge University Press, New York, 41-68.

Carroll, G. R. 1985. Concentration and specialization: Dynamics of niche width in populations of organizations. Amer. J. Sociology $901262-1283$.

Clarke, D. C. 2003. How do we know when an enterprise exists? Unanswerable questions and legal polycentricity in China. Working paper, University of Washington School of Law, Seattle, WA.

Coase, R. H. 1937. The nature of the firm. Economica 4(16) 386-405.

Coleman, J. S. 1964. Introduction to Mathematical Sociology. Free Press, New York.

Cook, T. D., D. T. Campbell, L. Peracchio. 1990. Quasi experimentation. M. D. Dunnette, L. M. Hough, eds. Handbook of Industrial \& Organizational Psychology, 2nd ed. Consulting Psychologists Press, Palo Alto, CA, 491-576.

D'Aunno, T., M. Succi, J. A. Alexander. 2000. The role of institutional and market forces in divergent organizational change. Admin. Sci. Quart. 45 679-703.

Davis, G. F. 2005. Firms and environments. N. Smelser, R. Swedberg, eds. Handbook of Economic Sociology, 2nd ed. Russell Sage/ Princeton University Press, Princeton, NJ, 478-502.

Davis, G. F., H. R. Greve. 1997. Corporate elite networks and governance changes in the 1980s. Amer. J. Sociology 103 1-37.

Davis, G. F., C. Marquis. 2005. The globalization of stock markets and convergence in corporate governance. R. Swedberg, V. Nee, eds. The Economic Sociology of Capitalism. Princeton University Press, Princeton, NJ, 352-390. 
Davis, G. F., M. Useem. 2002. Top management, company directors, and corporate control. A. Pettigrew, H. Thomas, R. Whittington, eds. Handbook of Strategy and Management. Sage, London, UK, 233-259.

DiMaggio, P. J., W. W. Powell. 1983. The iron cage revisited: Institutional isomorphism and collective rationality in organizational fields. Amer. Sociological Rev. 48 147-160.

Dobbin, F., J. R. Sutton. 1998. The strength of a weak state: The rights revolution and the rise of human resources management divisions. Amer. J. Sociology 104 441-476.

Edelman, L. B. 1992. Legal ambiguity and symbolic structures: Organizational mediation of civil rights law. Amer. J. Sociology 97 $1531-1576$.

Elster, J. 1998. A plea for mechanisms. P. Hedstrom, R. Swedberg, eds. Social Mechanisms: An Analytical Approach to Social Theory. Cambridge University Press, New York, 45-73.

Granovetter, M. 1994. Business groups. N. J. Smelser, R. Swedberg, eds. Handbook of Economic Sociology. Princeton University Press, Princeton, NJ, 453-475.

Hannan, M. T., J. Freeman. 1977. The population ecology of organizations. Amer. J. Sociology 82 929-964.

Harvey, D. 1990. The Condition of Postmodernity: An Enquiry into the Origins of Cultural Change. Blackwell, Cambridge, MA.

Hedstrom, P., R. Swedberg. 1998. Social Mechanisms: An Analytical Approach to Social Theory. Cambridge University Press, New York.

Hernes, G. 1998. Real virtuality. P. Hedstrom, R. Swedberg, eds. Social Mechanisms: An Analytical Approach to Social Theory. Cambridge University Press, New York, 74-101.

Hoffman, A. J. 1999. Institutional evolution and change: Environmentalism and the US chemical industry. Acad. Management J. 42 351-371.

Hoffman, A. J. 2001a. From Heresy to Dogma: An Institutional History of Corporate Environmentalism (expanded edition). Stanford University Press, Stanford, CA.

Hoffman, A. J. 2001b. Linking organizational and field-level analyses: The diffusion of corporate environmental practice. Organ. Environment 14 133-156.

Jensen, M. C., W. H. Meckling. 1976. Theory of the firm: Managerial behavior, agency cost, and ownership structure. J. Financial Econom. 3 305-360.

Kushner, T. 1994. Angels in America, Part Two: Perestroika. Theatre Communications Group, New York

Lawrence, P. R., J. W. Lorsch. 1967. Differentiation and integration in complex organizations. Admin. Sci. Quart. 12 1-47.

Lazerson, M. 1995. A new phoenix? Modern putting-out in the Modena knitwear industry. Admin. Sci. Quart. 40 34-59.

Lounsbury, M. 2001. Institutional sources of practice variation: Staffing college and university recycling programs. Admin. Sci. Quart. 46 29-56.

Lounsbury, M., M. J. Ventresca. 2002. Social structure and organizations revisited. M. Lounsbury, M. J. Ventresca, eds. Social Structure and Organizations Revisited: Research in the Sociology of Organizations, Vol. 19. JAI/Elsevier, Amsterdam, The Netherlands, 3-36.

March, J. G., H. A. Simon. 1958. Organizations. Wiley, New York.

Marquis, C. 2003. The pressure of the past: Network imprinting in intercorporate communities. Admin. Sci. Quart. 48 655-689.

Martin, J. L. 2003. What is field theory? Amer. J. Sociology 109 1-49.
McAdam, D., W. R. Scott. 2005. Organizations and movements. G. F. Davis, D. McAdam, W. R. Scott, M. N. Zald, eds. Social Movements and Organization Theory. Cambridge University Press, New York, 4-40.

McAdam, D., S. Tarrow, C. Tilly. 2001. Dynamics of Contention. Cambridge University Press, New York.

Meyer, J. W., B. Rowan. 1977. Institutionalized organizations: Formal structure as myth and ceremony. Amer. J. Sociology 83 41-62.

Mills, C. W. 1959. The Sociological Imagination. Oxford, New York.

North, D. C. 1990. Institutions, Institutional Change and Economic Performance. Cambridge University Press, Cambridge, UK.

Perrow, C. 1991. A society of organizations. Theory Soc. 20 725-762.

Pfeffer, J. 1993. Barriers to the advance of organizational science: Paradigm development as a dependent variable. Acad. Management Rev. 18 599-620.

Pfeffer, J., G. R. Salancik. 1978. The External Control of Organizations: A Resource Dependence Perspective. Harper \& Row, New York.

Piore, M. J., C. F. Sabel. 1984. The Second Industrial Divide. Basic, New York.

Robbins, G. E. 2002. Titles and Tasks: New Jobs for New Media in Silicon Alley? Unpublished doctoral dissertation, Columbia University, New York.

Sabel, C. F., J. Zeitlin. 1996. Stories, strategies, structures: Rethinking historical alternatives to mass production. C. F. Sabel, J. Zeitlin, eds. Worlds of Possibility: Flexibility and Mass Production in Western Industrialization. Cambridge University Press, Cambridge, UK

Saxenian, A. 1994. Regional Advantage: Culture and Competition in Silicon Valley and Route 128. Harvard University Press, Cambridge, MA.

Scott, W. R. 1995. Institutions and Organizations. Sage, Thousand Oaks, CA

Scott, W. R., M. Ruef, P. J. Mendel, C. A. Caronna. 2000. Institutional Change and Healthcare Organizations. University of Chicago Press, Chicago, IL.

Singh, J. V., R. J. House, D. J. Tucker. 1986. Organizational change and organizational mortality. Admin. Sci. Quart. 31 587-611.

Sørensen, A. B. 1998. Theoretical mechanisms and the empirical study of social processes. P. Hedstrom, R. Swedberg, eds. Social Mechanisms: An Analytical Approach to Social Theory. Cambridge University Press, New York, 238-266.

Stinchcombe, A. L. 1965. Social structure and organizations. J. G. March, ed. Handbook of Organizations. Rand McNally, Chicago, IL, 142-193.

Stinchcombe, A. L. 1968. Constructing Social Theories. University of Chicago Press, Chicago, IL.

Stinchcombe, A. L. 2002. New sociological microfoundations for organizational theory: A postscript. M. Lounsbury, M. J. Ventresca, eds. Social Structure and Organizations Revisited: Research in the Sociology of Organizations, Vol. 19. JAI/Elsevier, Amsterdam, The Netherlands, 415-433.

Stokes, D. E. 1997. Pasteur's Quadrant: Basic Science and Technological Innovation. Brookings Institution Press, Washington, D.C.

Strang, D., S. A. Soule. 1998. Diffusion in organizations and social movements: From hybrid corn to poison pills. Annual Rev. Sociology 24 265-290.

Sutton, J. R., F. Dobbin. 1996. The two faces of governance: Responses to legal uncertainty in U.S. firms, 1955 to 1985. Amer. Sociological Rev. 61 794-811. 
Thompson, J. D. 1967. Organizations in Action. McGraw Hill, New York.

Thornton, P. H., W. Ocasio. 1999. Institutional logics and the historical contingency of power in organizations: Executive succession in the higher education publishing industry, 1958-1990. Amer. J. Sociology 105 801-843.

Williamson, O. E. 1975. Markets and Hierarchies: Analysis and Antitrust Implications. Free Press, New York. 